\title{
Synthesis of Ethylene/1-Octene Copolymers with Ultrahigh Molecular Weights by Zr and Hf Complexes Bearing Bidentate NN Ligands with the Camphyl Linker
}

\author{
Chunyu Feng ${ }^{1}$, Qingqiang Gou ${ }^{2}$, Shaofeng Liu ${ }^{1, *} \mathbb{D}$, Rong Gao ${ }^{2, *}$ and Zhibo Li ${ }^{1,3, *}$ \\ 1 Key Laboratory of Biobased Polymer Materials, College of Polymer Science and Engineering, \\ Qingdao University of Science and Technology, Qingdao 266042, China; ffancy7@163.com \\ 2 Department of Polyethylene, Sinopec Beijing Research Institute of Chemical Industry, Beijing 100013, China; \\ gouqq.bjhy@sinopec.com \\ 3 College of Chemical Engineering, Qingdao University of Science and Technology, Qingdao 266042, China \\ * Correspondence: shaofengliu@qust.edu.cn (S.L.); gaor.bjhy@sinopec.com (R.G.); zbli@qust.edu.cn (Z.L.)
}

check for updates

Citation: Feng, C.; Gou, Q.; Liu, S.; Gao, R.; Li, Z. Synthesis of

Ethylene/1-Octene Copolymers with Ultrahigh Molecular Weights by $\mathrm{Zr}$ and Hf Complexes Bearing Bidentate NN Ligands with the Camphyl Linker. Catalysts 2021, 11, 276. https://doi.org/10.3390/catal11020276

Academic Editors: Carl Redshaw and Gregory A. Solan

Received: 29 January 2021

Accepted: 17 February 2021

Published: 18 February 2021

Publisher's Note: MDPI stays neutral with regard to jurisdictional claims in published maps and institutional affiliations.

Copyright: (c) 2021 by the authors. Licensee MDPI, Basel, Switzerland. This article is an open access article distributed under the terms and conditions of the Creative Commons Attribution (CC BY) license (https:/ / creativecommons.org/licenses/by/ $4.0 /)$

\begin{abstract}
Ultrahigh molecular weight polyethylene (UHMWPE) is a class of high-performance engineering plastics, exhibiting a unique set of properties and applications. Although many advances have been achieved in recent years, the synthesis of UHMWPE is still a great challenge. In this contribution, a series of zirconium and hafnium complexes, $\left[2,6-\left(\mathrm{R}^{1}\right)_{2}-4-\mathrm{R}^{2}-\mathrm{C}_{6} \mathrm{H}_{2}-\mathrm{N}-\mathrm{C}(\right.$ camphyl $)=\mathrm{C}$ (camphyl)- N2,6- $\left.\left(\mathrm{R}^{1}\right)_{2}-4-\mathrm{R}^{2}-\mathrm{C}_{6} \mathrm{H}_{2}\right] \mathrm{MMe}_{2}$ (THF) (1-Zr: $\mathrm{R}^{1}=\mathrm{Me}, \mathrm{R}^{2}=\mathrm{H}, \mathrm{M}=\mathrm{Zr} ; \mathbf{2 - Z r}: \mathrm{R}^{1}=\mathrm{Me}, \mathrm{R}^{2}=\mathrm{Me}, \mathrm{M}=\mathrm{Zr}$; 1-Hf: $\mathrm{R}^{1}=\mathrm{Me}, \mathrm{R}^{2}=\mathrm{H}, \mathrm{M}=\mathrm{Hf}$; 2 -Hf: $\mathrm{R}^{1}=\mathrm{Me}, \mathrm{R}^{2}=\mathrm{Me}, \mathrm{M}=\mathrm{Hf}$ ), bearing bidentate NN ligands with the bulky camphyl backbone were synthesized by the stoichiometric reactions of $\alpha$-diimine ligands with $\mathrm{MMe}_{4}(\mathrm{M}=\mathrm{Hf}$ or $\mathrm{Zr})$. All $\mathrm{Zr}$ and $\mathrm{Hf}$ metal complexes were analyzed using ${ }^{1} \mathrm{H}$ and ${ }^{13} \mathrm{C} \mathrm{NMR} \mathrm{spec}-$ troscopy, and the molecular structures of complexes 1-Zr and 1-Hf were determined by single-crystal $X$-ray diffraction, revealing that the original $\alpha$-diimine ligand was selectively reduced into the enediamido form and generated an 1,3-diaza-2-metallocyclopentene ring in the metal complexes. Zr complexes 1-Zr and 2-Zr showed moderate activity (up to $388 \mathrm{~kg}(\mathrm{PE}) \cdot \mathrm{mol}^{-1}(\mathrm{M}) \cdot \mathrm{h}^{-1}$ ), poor copolymerization ability, but unprecedented molecular weight capability toward ethylene/1-octene copolymerization. Therefore, copolymers with ultrahigh molecular weights $\left(>600\right.$ or $337 \times 10^{4} \mathrm{~g} \cdot \mathrm{mol}^{-1}$ ) were successfully synthesized by $\mathbf{1 - Z r}$ or $\mathbf{2 - Z r}$, respectively, with the borate cocatalyst $\left[\mathrm{Ph}_{3} \mathrm{C}\right]\left[\mathrm{B}\left(\mathrm{C}_{6} \mathrm{~F}_{5}\right)_{4}\right]$. Surprisingly, Hf complexes 1-Hf and 2-Hf showed negligible activity under otherwise identical conditions, revealing the great influence of metal centers on catalytic performances.
\end{abstract}

Keywords: $\alpha$-diimine; zirconium; hafnium; ene-diamido metal complexes; ethylene; copolymerization; ultrahigh molecular weight polyethylene

\section{Introduction}

The compound $\alpha$-diimine has been employed as an important synthetic ligand in the fields of coordination chemistry and olefin polymerization [1-4]. In the middle 1990s, Brookhart and co-workers reported their landmark research on cationic $\alpha$-diimine based $\mathrm{Ni}$ and Pd catalysts that builds a new era in the olefin polymerization field [5]. For example, branched polyolefins have been previously produced through copolymerization of ethylene with $\alpha$-olefins by early transition metal catalysts [6-9], while Brookhart-type $\alpha$-diimine based late transition metal catalysts can synthesize such branched polymers using ethylene as the only feed via the unique chain walking mechanism [10,11]. Moreover, $\mathrm{Ni}$ and $\mathrm{Pd}$ late transition metal catalysts have low oxophilicity, and thus show great potential for copolymerization of olefins with polar comonomers [12,13]. In the last two decades, this class of catalysts has received increasing research interest owing to their versatile structures, easy synthesis, and capability to tune structures of products [14]. Therefore, low molecular weight oligomers [15-17], ultrahigh molecular weights polyethylenes (UHMWPE) [18,19], 
highly branched [20] or linear [21-23] polymers are readily prepared by facilely tuning the substituents and backbone of ligands [24,25]. Besides, living polymerization of $\alpha$-olefins has been also achieved by the delicate design of $\alpha$-diimine based catalysts [26,27].

Although $\alpha$-diimine compounds have been intensively investigated as supporting ligands for late transition metal catalysts in the field of olefin polymerization, they are rarely used as ligand precursors for early transition metal catalysts. In 2007, Klosin and coworkers reported imino-amido $\mathrm{Zr}$ and $\mathrm{Hf}$ tribenzyl complexes, which were synthesized by the reaction of $\alpha$-diimine ligand with $\mathrm{M}\left(\mathrm{CH}_{2} \mathrm{Ph}\right)_{4}(\mathrm{M}=\mathrm{Zr}$ or Hf) and showed good activity toward ethylene/1-octene copolymerizations [28]. However, using imino-amido $\mathrm{Zr}$ and $\mathrm{Hf}$ tribenzyl complexes as catalysts for olefin polymerizations is limited, because they are usually unstable at high temperature and would go through dibenzyl elimination to form ene-diamido complexes, which exhibit relatively lower activity and form polymers with lower molecular weights and broad distributions [29]. Therefore, increasing the thermal stability of $\alpha$-diimine based metal complexes is highly desired for developing new olefin polymerization catalysts. For late transition metal complexes, the modifications of $N$-aryl substituents of $\alpha$-diimine ligands have been successfully employed to improve their thermal stability. Ionkin and coworkers reported that ortho-difurylaryl-substituted $\mathrm{Ni}$ $\alpha$-diimine catalysts displayed unprecedently stability under $150^{\circ} \mathrm{C}$ for ethylene polymerization [30]. More recently, Sun, Long, Chen, and others reported the benzhydryl-derived ligands could extremely enhance the thermal stability of $\alpha$-diimine catalysts [23,31-36]. On the other hand, the modification of the backbone of $\alpha$-diimine ligand is an alternative to tuning the catalytic properties of $\alpha$-diimine catalysts [37-39]. Gao and $\mathrm{Wu}$ and coworkers reported $\alpha$-diimine Ni complexes with the bulky camphyl backbone, which display excellent thermal stability and produce polymers with high molecular weights [40-42]. For early transition metal catalysts, a series of $\alpha$-diimine derivatives including imine-enamide and amide-quinoline have been used to support $\mathrm{Zr}$ and $\mathrm{Hf}$ complexes [43-49], but direct modifications of $N$-aryl substituents or backbones of $\alpha$-diimine ligands are undeveloped. Inspired by these studies, we report herein the synthesis of $\mathrm{Zr}$ and $\mathrm{Hf}$ complexes from $\alpha$-diimine ligands with the bulky camphyl backbone. Surprisingly, ene-diamido $\mathrm{Zr}$ and Hf complexes were selectively obtained as indicated by the analysis of NMR spectroscopy and X-ray diffraction. Copolymerization of ethylene and 1-octene with these metal complexes have been investigated, and the preliminary results show that $\mathrm{Zr}$ complexes have moderate activity (up to $388 \mathrm{~kg}(\mathrm{PE}) \cdot \mathrm{mol}^{-1}(\mathrm{M}) \cdot \mathrm{h}^{-1}$ ), poor copolymerization ability (less than $1 \mathrm{~mol} \%)$, but unprecedented molecular weight capability $\left(>600 \times 10^{4} \mathrm{~g} \cdot \mathrm{mol}^{-1}\right)$ toward ethylene/1-octene copolymerization, while Hf complexes show negligible activity under otherwise identical conditions. Note that Ultrahigh molecular weight polyethylenes (UHMWPE) have a unique set of properties such as high chemical resistance, outstanding mechanical property, good corrosion stability, excellent abrasive wear resistance, and thus are extensively used as a class of high-performance engineering plastics [50,51].

\section{Results and Discusssion}

The $\alpha$-diimine ligands $\mathbf{1}$ and $\mathbf{2}$ with the camphyl linker were prepared according to literature procedures [42]. According to previous report, imino-amido tribenzyl $\mathrm{Zr}$ complexes were readily prepared through the reaction of $\alpha$-diimine ligand with $\mathrm{ZrBn}_{4}$ via migratory insertion of one benzyl group into one $\mathrm{C}=\mathrm{N}$ bond [48]. In this study, $\mathrm{ZrCl}_{4}$ reacted with 4 equivalents of $\mathrm{MeMgBr}$ at low temperature (about $-40{ }^{\circ} \mathrm{C}$ ) in toluene to give $\mathrm{ZrMe}_{4}$, which was further used in situ to react with $\alpha$-diimine ligands to form methyl Zr complexes (Scheme 1) [43,52]. In contrast to previous report [28], the desired imino-amido $\mathrm{Zr}$ complexes did not formed and ene-diamido complexes $\mathbf{1 - Z r}$ and $\mathbf{2 - Z r}$ were exclusively obtained. Using the similar method, the corresponding Hf complexes 1-Hf and 2-Hf were also prepared as yellow solids. The NMR spectroscopic data of the $\mathrm{Zr}$ and Hf complexes (Figures S1-S8) are consistent with the presence of distinct ene-diamido structure. For example, the ${ }^{13} \mathrm{C}$ NMR signals of the $\mathrm{C}$ atoms of the camphyl backbone in $\mathbf{1 - Z r}$ appear in the olefinic range, 119.08 and $117.44 \mathrm{ppm}$ (Figure S2), respectively. 
In both ${ }^{1} \mathrm{H}$ and ${ }^{13} \mathrm{C}$ NMR spectra, each pair of substituents on the $\mathrm{N}$ atoms exhibits two characteristic sets of resonances, suggesting a $C_{1}$-symmetric structure due to the unsymmetric camphyl backbone. The broad signals at 3.53 and 1.08 ppm (Figure S1), whose integrations correspond to four protons, indicate the presence of one coordinated THF molecule [53].

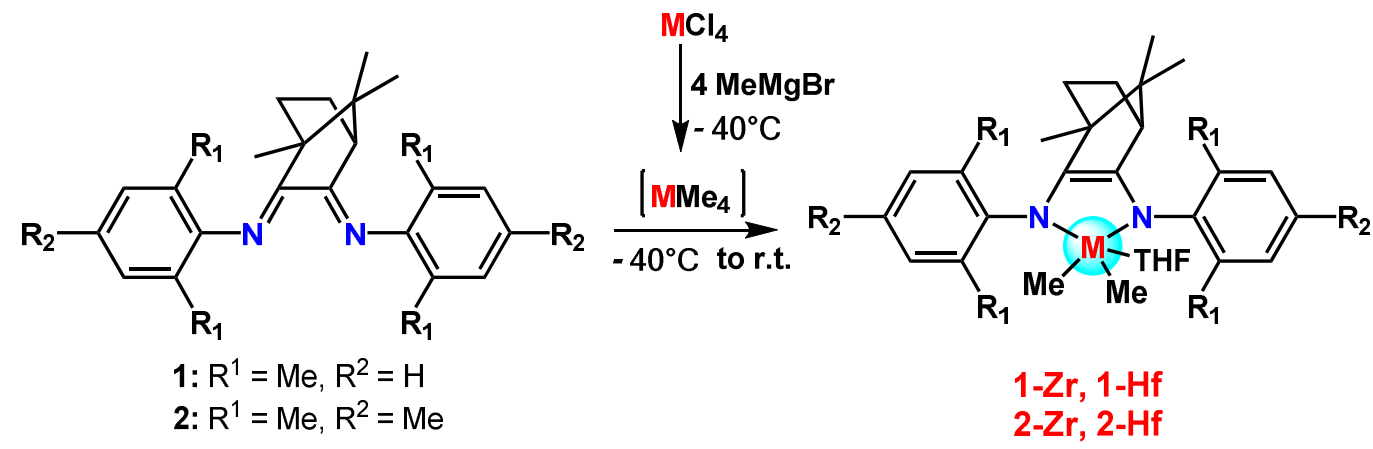

Scheme 1. Synthesis of $\mathrm{Zr}$ and Hf Complexes.

Furthermore, the distinct ene-diamido characteristics was determined by the $\mathrm{X}$-ray analyses of $\mathbf{1 - Z r}$ and $\mathbf{1 - H f}$. Single crystals of $\mathbf{1 - Z r}$ and $\mathbf{1 - H f}$ were obtained from their $n$-hexane solutions under $-30^{\circ} \mathrm{C}$, and their structures in the solid states are shown in Figures 1 and 2. Complex 1-Zr exhibits a distorted trigonal bipyramidal coordination at $\mathrm{Zr}$ metal centre (Figure 1). In total, two axial positions were taken by one ene-diamido nitrogen (N1) and oxygen of THF (O1), while the other ene-diamido nitrogen (N2) and two Me groups (C31 and C32) are located at the equatorial positions. The Zr1 atom deviates from the equatorial plane by $0.201 \AA$, and thus the sum of N2-Zr1-C31 $\left(129.14(12)^{\circ}\right), \mathrm{C} 31-\mathrm{Zr} 1-\mathrm{C} 32$ $\left(110.30(13)^{\circ}\right)$ and $\mathrm{N} 2-\mathrm{Zr} 1-\mathrm{C} 32\left(118.03(13)^{\circ}\right)$ is $357.47^{\circ}$ that is less than $360^{\circ}$. In comparison to the free ligand such as $4-\mathrm{Me}-\mathrm{C}_{6} \mathrm{H}_{4}-\mathrm{N}=\mathrm{C}(\mathrm{Me}) \mathrm{C}(\mathrm{Me})=\mathrm{N}-\mathrm{C}_{6} \mathrm{H}_{4}-4-\mathrm{Me}(1.499(12) \AA)$, the $\mathrm{C} 15-\mathrm{C} 16$ distance of the backbone in 1-Zr (C15-C16 1.386(4) $\AA$ ) is much shorter [54]. On the other hand, the N1-C16 (1.405(4) $\AA$ ) and N2-C15 (1.398(4) $\AA$ ) distances are significantly longer as compared with those in 4-Me- $\mathrm{C}_{6} \mathrm{H}_{4}-\mathrm{N}=\mathrm{C}(\mathrm{Me}) \mathrm{C}(\mathrm{Me})=\mathrm{N}-\mathrm{C}_{6} \mathrm{H}_{4}-4-\mathrm{Me}$ $(1.288(7) \AA)$ [54]. Thus, these results strongly suggest that the initial $\alpha$-diimine ligand was double reduced into the ene-diamido formation that generates a five-membered ring 1,3-diaza-2-zirconacyclopentene ring in $\mathbf{1 - Z r}$, which is folded along the N-N vector by an angle of $136.75^{\circ}$. Nevertheless, the distances Zr1-C15 (2.541(3) $\AA$ ) and Zr1-C16 (2.573(3) $\left.\mathrm{A}\right)$ are so short that the $\mathrm{Zr}$ atom could interact with the $\pi$-bond $(\mathrm{C} 15=\mathrm{C} 16)$, forming a $\sigma^{2}, \pi$ ene-diamido structure. On the other hand, the sum of angles at N1 and N2 are $359.96^{\circ}$ and $358.89^{\circ}$, respectively, revealing a sp ${ }^{2}$-planar geometry around $\mathrm{N}$ atoms. These results suggest that the $\sigma$ lone pairs of $\mathrm{N}$ atoms could be the potential reason leading to the formation of the unique $\sigma^{2}, \pi$-ene-diamido structure [55]. Complex 1-Hf possesses the same coordination feature (Figure 2) as that of complex 1-Zr, and thus it could be speculated that 2-Zr and 2-Hf may possess a similar coordination feature.

Complexes 1-Zr, 2-Zr, 1-Hf and 2-Hf were preliminarily evaluated as catalysts for ethylene/1-octene copolymerization at $120^{\circ} \mathrm{C}$ under $3 \mathrm{MPa}$ of ethylene pressure, and the data are presented in Table 1 . According to previous report, the ene-diamido complexes usually showed a lower activity in comparison to that of the imino-amido complexes [28]. In the presence of $\left[\mathrm{Ph}_{3} \mathrm{C}\right]\left[\mathrm{B}\left(\mathrm{C}_{6} \mathrm{~F}_{5}\right)_{4}\right]$ as cocatalyst, $\mathbf{1 - Z r}$ and $\mathbf{2 - Z r}$ exhibited moderate activity toward ethylene/1-octene copolymerization (Table 1, Runs 1 and 2). It is worth noting that subtle changes in ligand resulted in $\mathbf{1 - Z r}$ and $2-\mathrm{Zr}$ showing quite different activity and polymer molecular weight capability. $2-\mathbf{Z r}$, with one more methyl on the paraposition of the aryl group, exhibited a higher activity $\left(388 \mathrm{~kg}(\mathrm{PE}) \cdot \mathrm{mol}^{-1}(\mathrm{M}) \cdot \mathrm{h}^{-1}\right)$ than $\mathbf{1 - Z r}$ $\left(236 \mathrm{~kg}(\mathrm{PE}) \cdot \mathrm{mol}^{-1}(\mathrm{M}) \cdot \mathrm{h}^{-1}\right)$. In contrast to previous reports that ene-diamido complexes usually formed polymers with low molecular weights and broad distributions [28,29], 1-Zr and $2-Z r$ in this study displayed remarkable molecular weight capability and produced 
ultrahigh molecular weight polyethylene (UHMWPE). A polymer sample with molecular weight as high as $337 \times 10^{4} \mathrm{~g} \cdot \mathrm{mol}^{-1}$ was synthesized by $2-\mathrm{Zr} /\left[\mathrm{Ph}_{3} \mathrm{C}\right]\left[\mathrm{B}\left(\mathrm{C}_{6} \mathrm{~F}_{5}\right)_{4}\right]$ (Figure S9), which is much higher than previous reports $[28,29,46-49]$. The polymer prepared by 1-Zr $/\left[\mathrm{Ph}_{3} \mathrm{C}\right]\left[\mathrm{B}\left(\mathrm{C}_{6} \mathrm{~F}_{5}\right)_{4}\right]$ possessed an even higher molecular weight, which should be over $600 \times 10^{4} \mathrm{~g} \cdot \mathrm{mol}^{-1}$ but could not be accurately calibrated because of the limitation of GPC equipment. Molecular weights determined through universal calibration relative to polystyrene standards in our hand are only effective in the range of $10^{3} \mathrm{~g} \cdot \mathrm{mol}^{-1}$ to $600 \times 10^{4} \mathrm{~g} \cdot \mathrm{mol}^{-1}$. On the other hand, the copolymerization ability of $\mathbf{1 - Z r}$ and $\mathbf{2 - Z r}$ were poor in comparison to previously reported imino-amido analogues [28], and less than $1 \mathrm{~mol} \%$ of 1-octene were incorporated in this study (Table 1, Runs 1 and 2; Figures S10 and S11). Hf complexes were also tested under otherwise identical conditions, and it is surprising that only trace polymers were obtained by $\mathbf{1}-\mathbf{H f}$ and $\mathbf{2}-\mathbf{H f}$. These results suggest that the catalytic properties highly depend on both the structure of ligands and the nature of the metal centers.

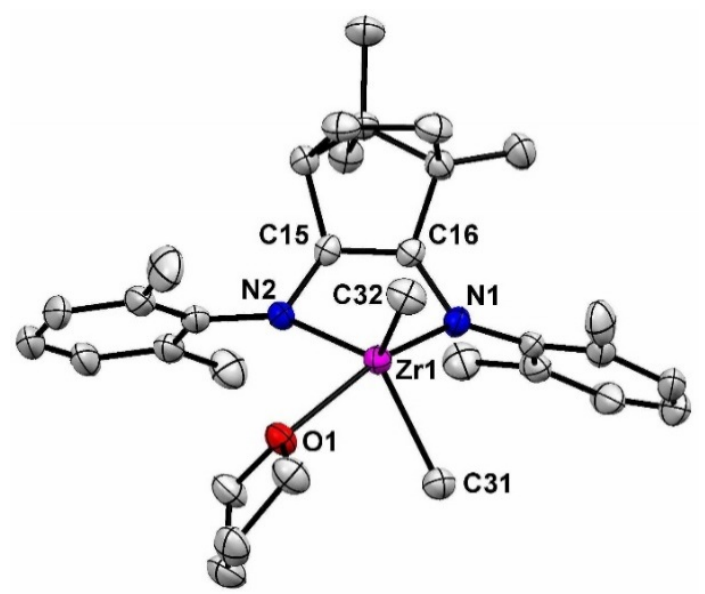

Figure 1. Molecular structure of 1-Zr. Selected distances ( $\mathrm{A})$ and angles (deg): Zr1-N1 2.067(3), Zr1-N2 2.079(3), Zr1-O1 2.305(3), Zr1-C31 2.279(4), Zr1-C32 2.270(3), Zr1-C15 2.541(3), Zr1-C16 (2.573(3), C15-C16 1.386(4), N1-C16 1.405(4), N2-C15 1.398(4); N2-Zr1-C31 129.14(12), C31-Zr1-C32 110.30(13), N2-Zr1-C32 118.03(13), N1-Zr1-O1 158.04(9), N1-Zr1-N2 89.52(10).

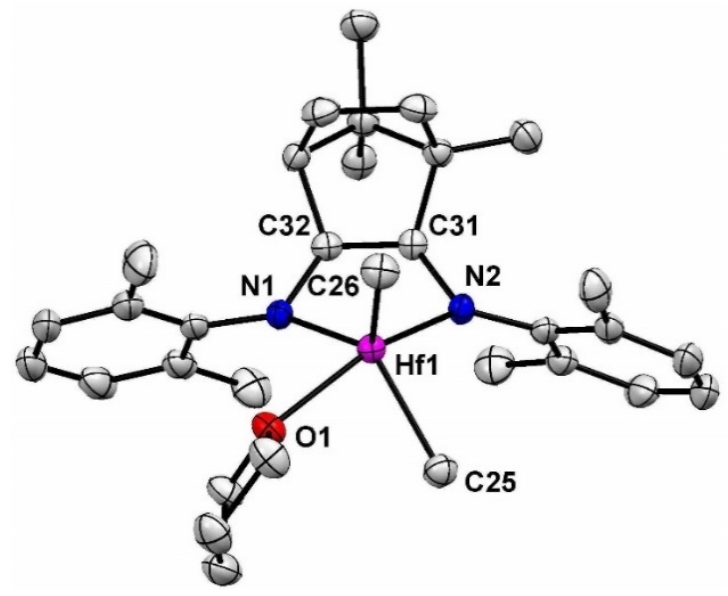

Figure 2. Molecular structure of 1-Hf. Selected distances ( $\AA$ ) and angles (deg): Hf1-N1 2.060(2), Hf1-N2 2.053(2), Hf1-O1 2.2732(19), Hf1-C25 2.255(3), Hf1-C26 2.246(3), Hf1-C31 2.581(2), Hf1-C32 2.560(3), C31-C32 1.369(4), N1-C32 1.412(3), N2-C31 1.400(3); N1-Hf1-C25 130.41(11), C25-Hf1-C26 110.25(12), N1-Hf1-C26 116.56(11), N2-Hf1-O1 160.03(8), N1-Hf1-N2 89.69(9). 
Table 1. Ethylene/1-Octene Copolymerization by Zr and Hf Complexes. ${ }^{1}$

\begin{tabular}{|c|c|c|c|c|c|c|c|}
\hline Run & Cat. & $\begin{array}{l}\text { PE } \\
\text { (g) }\end{array}$ & act. ${ }^{2}$ & $\begin{array}{c}M_{\mathrm{w}}^{3} \\
\left(10^{4} \mathrm{~g} \cdot \mathrm{mol}^{-1}\right)\end{array}$ & $\boxplus^{3}$ & $\begin{array}{l}T_{\mathrm{m}}{ }^{4} \\
\left({ }^{\circ} \mathrm{C}\right)\end{array}$ & $\begin{array}{c}\text { Octene Incorp. } \\
(\mathrm{mol} \%)\end{array}$ \\
\hline 1 & $1-\mathrm{Zr}$ & 0.393 & 236 & $>600$ & - & 126 & 0.2 \\
\hline 2 & $2-Z r$ & 0.647 & 388 & 337 & 3.3 & 126 & 1.0 \\
\hline 3 & 1-Hf & trace & - & - & - & - & - \\
\hline 4 & 2-Hf & trace & - & - & - & - & - \\
\hline
\end{tabular}

${ }^{1}$ Conditions: $10 \mu \mathrm{mol}$ metal complexes, cocatalysts $\left[\mathrm{Ph}_{3} \mathrm{C}\right]\left[\mathrm{B}\left(\mathrm{C}_{6} \mathrm{~F}_{5}\right)_{4}\right] / \mathrm{M}=1.2 ; 3 \mathrm{MPa}$ of ethylene, $220 \mathrm{~g}$ toluene, $120 \mathrm{~g}$ 1-octene, $120{ }^{\circ} \mathrm{C}$, $10 \mathrm{~min} .{ }^{2}$ In units of $\mathrm{kg}(\mathrm{PE}) \cdot \mathrm{mol}^{-1}(\mathrm{M}) \cdot \mathrm{h}^{-1} .{ }^{3}$ Determined by GPC using polystyrene as the standard. ${ }^{4}$ Determined by DSC. ${ }^{5}$ Octene content determined by ${ }^{13} \mathrm{C}$ NMR spectroscopy.

\section{Materials and Methods}

The compounds 2,6- $\left(\mathrm{R}^{1}\right)_{2}-4-\mathrm{R}^{2}-\mathrm{C}_{6} \mathrm{H}_{2}-\mathrm{N}=\mathrm{C}($ camphyl $)-\mathrm{C}($ camphyl $)=\mathrm{N}-2,6-\left(\mathrm{R}^{1}\right)_{2}-4-\mathrm{R}^{2}-$ $\mathrm{C}_{6} \mathrm{H}_{2}\left(1: \mathrm{R}^{1}=\mathrm{Me}, \mathrm{R}^{2}=\mathrm{H} ; 2: \mathrm{R}^{1}=\mathrm{R}^{2}=\mathrm{Me}\right)$ were synthesized using previously reported methods [42].

\subsection{Synthesis of $\mathbf{1 - Z r}$}

$\mathrm{ZrCl}_{4}(0.256 \mathrm{~g}, 1.1 \mathrm{mmol})$ was suspended in anhydrous toluene $(5 \mathrm{~mL})$, and the MeMgCl solution (1.6 mL, $4.8 \mathrm{mmol}, 3 \mathrm{M}$ in THF) was added slowly using a syringe at $-40{ }^{\circ} \mathrm{C}$. The resultant mixture was stirred at $-40^{\circ} \mathrm{C}$ for $1 \mathrm{~h}$, and then ligand $\mathbf{1}(0.372 \mathrm{~g}$, $1.0 \mathrm{mmol})$ in toluene $(8 \mathrm{~mL})$ was added at $-40^{\circ} \mathrm{C}$. The resultant suspension was stirred under $-40^{\circ} \mathrm{C}$ for $2 \mathrm{~h}$, and at ambient temperature for another $3 \mathrm{~h}$ that formed a dark-brown mixture. The volatiles were removed under reduced pressure to give an oil residue that was extracted with $n$-hexane for 3 times $(30,20,10 \mathrm{~mL})$. The yellow solid $\mathbf{1 - Z r}$ was obtained from the concentrated hexane solution with a yield of $64 \%(0.36 \mathrm{~g}, 0.64 \mathrm{mmol}) .{ }^{1} \mathrm{H}$ NMR $\left(400 \mathrm{MH}_{\mathrm{Z}}, \mathrm{C}_{6} \mathrm{D}_{6}\right): \delta 7.19-7.14(\mathrm{~m}, 2 \mathrm{H}), 7.09(\mathrm{t}, J=6.6 \mathrm{~Hz}, 2 \mathrm{H}), 6.99(\mathrm{t}, J=7.4 \mathrm{~Hz}, 2 \mathrm{H}), 3.53$ (br, 4 H, THF), $2.84(\mathrm{~s}, 3 \mathrm{H}, \mathrm{Me}), 2.47$ (s, $3 \mathrm{H}, \mathrm{Me}), 2.29$ (s, $3 \mathrm{H}, \mathrm{Me}), 2.25(\mathrm{~s}, 3 \mathrm{H}, \mathrm{Me}), 2.14(\mathrm{~d}$, $J=2.6 \mathrm{~Hz}, 1 \mathrm{H}), 1.88-180(\mathrm{~m}, 1 \mathrm{H}), 1.67-1.56(\mathrm{~m}, 2 \mathrm{H}), 1.34-1.30(\mathrm{~m}, 1 \mathrm{H}), 1.15(\mathrm{~s}, 3 \mathrm{H}, \mathrm{Me})$, 1.08 (br, 4 H, THF), 0.81 (s, 3 H, Me), 0.64 (s, 3 H, Me), 0.14 (br, 3 H, Hf-Me), 0.04 (s, 3 H, Hf-Me). ${ }^{13} \mathrm{C}$ NMR $\left(100 \mathrm{MH}_{\mathrm{Z}}, \mathrm{C}_{6} \mathrm{D}_{6}\right): \delta 150.60,150.37,135.67,133.47,133.36,133.21,128.52$, $128.49,128.18,127.94,124.50,123.81,119.08,117.44,70.75,57.58,52.13,51.59,34.65,27.88$, $25.13,21.47,20.35,20.27,20.17,19.96,19.91,12.56$. Analysis calculated for $\mathrm{C}_{32} \mathrm{H}_{46} \mathrm{~N}_{2} \mathrm{OZr}$ : C, $67.91 ; \mathrm{H}, 8.19 ; \mathrm{N}, 4.95$. Found: C, 68.03; H, 8.01; N, 4.78.

\subsection{Synthesis of $\mathbf{1 - H} f$}

$\mathrm{HfCl}_{4}(0.352 \mathrm{~g}, 1.1 \mathrm{mmol})$ was suspended in anhydrous toluene $(5 \mathrm{~mL})$, the $\mathrm{MeMgCl}$ solution ( $1.6 \mathrm{~mL}, 4.8 \mathrm{mmol}, 3 \mathrm{M}$ in THF) was added slowly using a syringe at $-40{ }^{\circ} \mathrm{C}$. The resultant mixture was stirred at $-40^{\circ} \mathrm{C}$ for $1 \mathrm{~h}$, and then ligand $1(0.372 \mathrm{~g}, 1.0 \mathrm{mmol})$ in toluene $(8 \mathrm{~mL})$ was added at $-40{ }^{\circ} \mathrm{C}$. The resultant suspension was stirred at $-40{ }^{\circ} \mathrm{C}$ for $2 \mathrm{~h}$, and then at ambient temperature for another $3 \mathrm{~h}$ that gives a dark-brown mixture. The volatiles were removed under reduced pressure to give a residue that was extracted with $n$-hexane for 3 times ( $30 \mathrm{~mL}, 20 \mathrm{~mL}, 10 \mathrm{~mL}$ ). The product 1-Hf as a yellow solid was obtained from the concentrated hexane solution with a yield of $69 \%(0.45 \mathrm{~g}, 0.69 \mathrm{mmol})$. ${ }^{1} \mathrm{H}$ NMR $\left(400 \mathrm{MH}_{Z}, \mathrm{C}_{6} \mathrm{D}_{6}\right): \delta 7.16(\mathrm{t}, J=7.9 \mathrm{~Hz}, 2 \mathrm{H}), 7.10(\mathrm{t}, J=7.3 \mathrm{~Hz}, 2 \mathrm{H}), 6.97(\mathrm{td}$, $J=7.4,2.5 \mathrm{~Hz}, 2 \mathrm{H}), 3.47$ (br, $4 \mathrm{H}, \mathrm{THF}), 2.82(\mathrm{~s}, 3 \mathrm{H}), 2.46(\mathrm{~s}, 3 \mathrm{H}), 2.36(\mathrm{~s}, 3 \mathrm{H}), 2.31(\mathrm{~s}, 3 \mathrm{H})$, $2.12(\mathrm{~d}, J=3.4 \mathrm{~Hz}, 1 \mathrm{H}), 1.85(\mathrm{ddd}, J=11.8,8.0,3.9 \mathrm{~Hz}, 1 \mathrm{H}), 1.70-1.58(\mathrm{~m}, 2 \mathrm{H}), 1.39-1.33$ $(\mathrm{m}, 1 \mathrm{H}), 1.12(\mathrm{~s}, 3 \mathrm{H}), 1.07(\mathrm{~s}, 4 \mathrm{H}, \mathrm{THF}), 0.78(\mathrm{~s}, 3 \mathrm{H}), 0.64(\mathrm{~s}, 3 \mathrm{H}),-0.03(\mathrm{~s}, 3 \mathrm{H}),-0.05$ (s, $3 \mathrm{H}) .{ }^{13} \mathrm{C}$ NMR $\left(100 \mathrm{MH}_{\mathrm{Z}}, \mathrm{C}_{6} \mathrm{D}_{6}\right): \delta 150.93,150.90,136.02,134.13,133.89,133.77,128.51$, 128.22, 128.16, 127.94, 124.52, 123.75, 118.65, 117.03, 70.71, 57.57, 52.13, 51.27, 47.79, 45.92, 25.10, 21.44, 20.38, 20.28, 20.02, 19.96, 19.88, 12.52. Analysis calculated for $\mathrm{C}_{32} \mathrm{H}_{46} \mathrm{HfN}_{2} \mathrm{O}: \mathrm{C}$, 58.84; H, 7.10; N, 4.29. Found: C, 58.51; H, 6.93; N, 4.04 . 


\subsection{Synthesis of $\mathbf{2}-\mathbf{Z r}$}

Using the method described for complex 1-Zr, 2-Zr was obtained as a yellow solid $(0.43 \mathrm{~g}, 0.72 \mathrm{mmol}, 72 \%) .{ }^{1} \mathrm{H}$ NMR $\left(400 \mathrm{MH}_{\mathrm{Z}}, \mathrm{C}_{6} \mathrm{D}_{6}\right): \delta 6.98(\mathrm{~d}, J=5.6 \mathrm{~Hz}, 2 \mathrm{H}), 6.90(\mathrm{~d}$, $J=6.7 \mathrm{~Hz}, 2 \mathrm{H}), 3.58(\mathrm{br}, 4 \mathrm{H}, \mathrm{THF}), 2.83(\mathrm{~s}, 3 \mathrm{H}), 2.46(\mathrm{~s}, 3 \mathrm{H}), 2.30(\mathrm{~s}, 3 \mathrm{H}), 2.26(\mathrm{~s}, 3 \mathrm{H}), 2.25$ $(\mathrm{s}, 3 \mathrm{H}), 2.23(\mathrm{~s}, 3 \mathrm{H}), 2.19(\mathrm{~d}, J=3.6 \mathrm{~Hz}, 1 \mathrm{H}), 1.87(\mathrm{ddd}, J=15.6,8.0,3.7 \mathrm{~Hz}, 1 \mathrm{H}), 1.71-1.56$ $(\mathrm{m}, 2 \mathrm{H}), 1.38-1.30(\mathrm{~m}, 1 \mathrm{H}), 1.19(\mathrm{~s}, 3 \mathrm{H}), 1.10(\mathrm{br}, 4 \mathrm{H}, \mathrm{THF}), 0.85(\mathrm{~s}, 3 \mathrm{H}), 0.66(\mathrm{~s}, 3 \mathrm{H}), 0.16$ (br, $3 \mathrm{H}), 0.05$ (s, $3 \mathrm{H}) .{ }^{13} \mathrm{C}$ NMR $\left(100 \mathrm{MH}_{\mathrm{Z}}, \mathrm{C}_{6} \mathrm{D}_{6}\right)$ : $\delta 148.08,147.78,135.30,133.23,133.09$, $133.02,132.83$, 132.42, 129.33, 129.24, 129.03, 128.96, 119.05, 117.26, 70.60, 57.58, 52.09, 51.61, 35.65, 34.69, 34.38, 27.88, 25.21, 21.40, 21.05, 20.98, 20.41, 20.21, 20.10, 20.01, 19.86, 12.68 . Anal. Calcd for $\mathrm{C}_{34} \mathrm{H}_{50} \mathrm{~N}_{2} \mathrm{OZr}$ : C, 68.75; H, 8.48; N, 4.72. Found: $\mathrm{C}, 68.44 ; \mathrm{H}, 8.31 ; \mathrm{N}, 4.65$.

\subsection{Synthesis of $\mathbf{2}-\mathrm{H} f$}

Using the method described for complex 1-Hf, 2-Hf was obtained as a yellow solid (0.57 g, $0.84 \mathrm{mmol}, 84 \%) .{ }^{1} \mathrm{H}$ NMR $\left(400 \mathrm{MH}_{\mathrm{Z}}, \mathrm{C}_{6} \mathrm{D}_{6}\right): \delta 6.99(\mathrm{~s}, 1 \mathrm{H}), 6.97(\mathrm{~s}, 1 \mathrm{H}), 6.93(\mathrm{~s}$, $2 \mathrm{H}), 3.50(\mathrm{br}, 4 \mathrm{H}, \mathrm{THF}), 2.83(\mathrm{~s}, 3 \mathrm{H}), 2.47(\mathrm{~s}, 3 \mathrm{H}), 2.39(\mathrm{~s}, 3 \mathrm{H}), 2.33(\mathrm{~s}, 3 \mathrm{H}), 2.27(\mathrm{~s}, 3$ $\mathrm{H}), 2.24(\mathrm{~s}, 3 \mathrm{H}), 2.18(\mathrm{~d}, J=2.2 \mathrm{~Hz}, 1 \mathrm{H}), 1.89(\mathrm{qd}, J=8.0,3.4 \mathrm{~Hz}, 1 \mathrm{H}), 1.75-1.60(\mathrm{~m}, 2 \mathrm{H})$, 1.44-1.34 (m, $1 \mathrm{H}), 1.17(\mathrm{~s}, 3 \mathrm{H}), 1.07$ (br, $4 \mathrm{H}, \mathrm{THF}), 0.84(\mathrm{~s}, 3 \mathrm{H}), 0.66(\mathrm{~s}, 3 \mathrm{H}), 0.00(\mathrm{br}, 6 \mathrm{H})$. ${ }^{13} \mathrm{C}$ NMR $\left(100 \mathrm{MH}_{\mathrm{Z}}, \mathrm{C}_{6} \mathrm{D}_{6}\right)$ : $\delta 148.36,148.31,135.68,133.75,133.56,133.42,133.24,132.39$, $129.33,129.29,128.94,128.89,118.61,116.91,70.78,57.59,52.11,51.33,47.34,45.71,34.75$, $28.08,25.14,21.36,21.01,20.95,20.42,20.21,19.97,19.95,19.83,12.53$. Analysis calculated for $\mathrm{C}_{34} \mathrm{H}_{50} \mathrm{HfN}_{2} \mathrm{O}: \mathrm{C}, 59.94 ; \mathrm{H}, 7.40 ; \mathrm{N}$, 4.11. Found: C, 60.12; H, 7.52; N, 4.01.

\section{Conclusions}

The reactions of $\alpha$-diimine ligands having the bulky camphyl backbone with $\mathrm{MMe}_{4}$ $(\mathrm{M}=\mathrm{Hf}$ or $\mathrm{Zr}$ ) led to the selective formation of ene-diamido $\mathrm{Zr}$ and Hf complexes. The ene-diamido structure has been characterized and determined by ${ }^{1} \mathrm{H}$ and ${ }^{13} \mathrm{C}$ NMR spectroscopy, and single-crystal X-ray diffraction. $\mathrm{Zr}$ complexes $\mathbf{1 - Z r}$ and $\mathbf{2 - Z r}$ showed moderate activity (236 and $388 \mathrm{~kg}(\mathrm{PE}) \cdot \mathrm{mol}^{-1}(\mathrm{M}) \cdot \mathrm{h}^{-1}$, respectively) toward ethylene/1-octene copolymerization at high temperature $\left(120^{\circ} \mathrm{C}\right)$ and high pressure ( $3 \mathrm{MPa}$ of ethylene) and produced copolymers with ultrahigh molecular weights. Under otherwise identical conditions, Hf complexes 1-Hf and 2-Hf exhibited only negligible activity. This study reveals that the catalytic properties, including activity, molecular weight capability and copolymerization ability, highly depend on the structure of $\alpha$-diimine ligands and the nature of the metal centers.

Supplementary Materials: The following are available online at https://www.mdpi.com/2073-4 344/11/2/276/s1, Figure S1: ${ }^{1} \mathrm{H}$ NMR spectrum of $1-\mathrm{Zr}$ in $\mathrm{C}_{6} \mathrm{D}_{6}$, Figure S2: ${ }^{13} \mathrm{C}$ NMR spectrum of 1-Zr in $\mathrm{C}_{6} \mathrm{D}_{6}$, Figure S3: ${ }^{1} \mathrm{H}$ NMR spectrum of 1-Hf in $\mathrm{C}_{6} \mathrm{D}_{6}$, Figure $\mathrm{S4}:{ }^{13} \mathrm{C}$ NMR spectrum of 1-Hf in $\mathrm{C}_{6} \mathrm{D}_{6}$, Figure S5: ${ }^{1} \mathrm{H}$ NMR spectrum of 2-Zr in $\mathrm{C}_{6} \mathrm{D}_{6}$, Figure $\mathrm{S6}:{ }^{13} \mathrm{C}$ NMR spectrum of 2-Zr in $\mathrm{C}_{6} \mathrm{D}_{6}$, Figure S7: ${ }^{1} \mathrm{H}$ NMR spectrum of 2-Hf in $\mathrm{C}_{6} \mathrm{D}_{6}$, Figure $\mathrm{S8}:{ }^{13} \mathrm{C}$ NMR spectrum of 2-Hf in $\mathrm{C}_{6} \mathrm{D}_{6}$, Figure S9: GPC curve of copolymer obtained in Table 1 Run $2\left(M_{\mathrm{W}}=337 \times 10^{4} \mathrm{~g} \cdot \mathrm{mol}^{-1}\right.$, $Ð=3.3)$, Figure S10: ${ }^{13} \mathrm{C}$ NMR spectrum of copolymer obtained in Table 1 run 1 in $\mathrm{C}_{2} \mathrm{D}_{2} \mathrm{Cl}_{4}$ at $120{ }^{\circ} \mathrm{C}$ (0.2 mol\% of 1-octene incorporation), Figure S11: ${ }^{3} \mathrm{C}$ NMR spectrum of copolymer obtained in Table 1 run 2 in $\mathrm{C}_{2} \mathrm{D}_{2} \mathrm{Cl}_{4}$ at $120{ }^{\circ} \mathrm{C}(1.0 \mathrm{~mol} \%$ of 1-octene incorporation), Table S1: Crystal data and structure refinement for metal complexes.

Author Contributions: Conceptualization, S.L., Q.G., and Z.L.; methodology, S.L.; data curation, C.F. and R.G.; writing —original draft preparation, C.F. and S.L.; writing—review and editing, S.L., R.G., and Z.L.; funding acquisition, S.L. All authors have read and agreed to the published version of the manuscript.

Funding: S.L. is thankful for financial support from the National Natural Science Foundation of China (Nos. 52073152 and 21871157), the 111 Project (No. D17004), Shandong Province Natural Science Foundation (No. ZR2018JL007), Shandong Provincial Education Department (No. 2019KJA001), and Taishan Scholar Constructive Engineering Foundation (No. tsqn20161031).

Institutional Review Board Statement: Not applicable. 
Informed Consent Statement: Not applicable.

Data Availability Statement: Not applicable.

Conflicts of Interest: The authors declare no conflict of interest.

\section{References}

1. Wang, F.; Chen, C. A continuing legend: The Brookhart-type $\alpha$-diimine nickel and palladium catalysts. Polym. Chem. 2019, 10, 2354-2369. [CrossRef]

2. Wang, Z.; Liu, Q.; Solan, G.A.; Sun, W.-H. Recent advances in Ni-mediated ethylene chain growth: Nimine-donor ligand effects on catalytic activity, thermal stability and oligo-/polymer structure. Coord. Chem. Rev. 2017, 350, 68-83. [CrossRef]

3. Kaiser, J.M.; Long, B.K. Recent developments in redox-active olefin polymerization catalysts. Coord. Chem. Rev. 2018, 372, 141-152. [CrossRef]

4. Mitchell, N.E.; Long, B.K. Recent advances in thermally robust, late transition metal-catalyzed olefin polymerization. Polym. Int. 2019, 68, 14-26. [CrossRef]

5. Johnson, L.K.; Killian, C.M.; Brookhart, M. New Pd(II)- and Ni(II)-Based Catalysts for Polymerization of Ethylene and $\alpha$-Olefins. J. Am. Chem. Soc. 1995, 117, 6414-6415. [CrossRef]

6. Invergo, A.M.; Liu, S.; Dicken, R.D.; Mouat, A.R.; Delferro, M.; Lohr, T.L.; Marks, T.J. How Close Is Too Close? Polymerization Behavior and Monomer-Dependent Reorganization of a Bimetallic Salphen Organotitanium Catalyst. Organometallics 2018, 37, 2429-2436. [CrossRef]

7. Liu, S.; Invergo, A.M.; McInnis, J.P.; Mouat, A.R.; Motta, A.; Lohr, T.L.; Delferro, M.; Marks, T.J. Distinctive Stereochemically Linked Cooperative Effects in Bimetallic Titanium Olefin Polymerization Catalysts. Organometallics 2017, 36, 4403-4421. [CrossRef]

8. Liu, S.; Motta, A.; Mouat, A.R.; Delferro, M.; Marks, T.J. Very Large Cooperative Effects in Heterobimetallic Titanium-Chromium Catalysts for Ethylene Polymerization/Copolymerization. J. Am. Chem. Soc. 2014, 136, 10460-10469. [CrossRef] [PubMed]

9. Liu, S.; Motta, A.; Delferro, M.; Marks, T.J. Synthesis, Characterization, and Heterobimetallic Cooperation in a TitaniumChromium Catalyst for Highly Branched Polyethylenes. J. Am. Chem. Soc. 2013, 135, 8830-8833. [CrossRef] [PubMed]

10. Guo, L.; Dai, S.; Sui, X.; Chen, C. Palladium and Nickel Catalyzed Chain Walking Olefin Polymerization and Copolymerization. ACS Catal. 2016, 6, 428-441. [CrossRef]

11. Guan, Z.; Cotts, P.M.; Mccord, E.F.; McLain, S.J. Chain Walking: A New Strategy to Control Polymer Topology. Sci. 1999, 283, 2059-2062. [CrossRef]

12. Tan, C.; Chen, C. Emerging Palladium and Nickel Catalysts for Copolymerization of Olefins with Polar Monomers. Angew. Chem. Int. Ed. 2019, 58, 7192-7200. [CrossRef]

13. Chen, E.Y.-X. Coordination Polymerization of Polar Vinyl Monomers by Single-Site Metal Catalysts. Chem. Rev. 2009, 109, 5157-5214. [CrossRef]

14. Guan, Z.; Popeney, C.S. Recent Progress in Late Transition Metal $\alpha$-Diimine Catalysts for Olefin Polymerization. Top. Organomet. Chem. 2009, 26, 179-220.

15. Ma, X.; Hu, X.; Zhang, Y.; Mu, H.; Cui, L.; Jian, Z. Preparation and in Situ Chain-end-functionalization of Branched Ethylene Pligomers by Monosubstituted $\alpha$-diimine Nickel Catalysts. Polym. Chem. 2019, 10, 2596-2607. [CrossRef]

16. Feng, C.; Zhou, S.; Wang, D.; Zhao, Y.; Liu, S.; Li, Z.; Braunstein, P. Cooperativity in Highly Active Ethylene Dimerization by Dinuclear Nickel Complexes Bearing a Bifunctional PN Ligand. Organometallics 2021, 40, 184-193. [CrossRef]

17. Zhang, J.; Liu, S.; Li, A.; Ye, H.; Li, Z. Nickel(ii) complexes chelated by 2,6-pyridinedicarboxamide: Syntheses, characterization, and ethylene oligomerization. New J. Chem. 2016, 40, 7027-7033. [CrossRef]

18. Wang, C.; Kang, X.; Dai, S.; Cui, F.; Li, Y.; Mu, H.; Mecking, S.; Jian, Z. Efficient Suppression of Chain Transfer and Branching via Cs-Type Shielding in a Neutral Nickel(II) Catalyst. Angew. Chem. 2021, 60, 4018-4022. [CrossRef] [PubMed]

19. Chen, Z.; Mesgar, M.; White, P.S.; Daugulis, O.; Brookhart, M. Synthesis of Branched Ultrahigh-Molecular-Weight Polyethylene Using Highly Active Neutral, Single-Component Ni(II) Catalysts. ACS Catal. 2015, 5, 631-636. [CrossRef]

20. Zhang, Y.; Wang, C.; Mecking, S.; Jian, Z. Ultrahigh Branching of Main-Chain-Functionalized Polyethylenes by Inverted Insertion Selectivity. Angew. Chem. Int. Ed. 2020, 59, 14296-14302. [CrossRef] [PubMed]

21. Leung, D.H.; Ziller, J.W.; Guan, Z. Axial Donating Ligands: A New Strategy for Late Transition Metal Olefin Polymerization Catalysis. J. Am. Chem. Soc. 2008, 130, 7538-7539. [CrossRef]

22. Dai, S.; Chen, C. Direct Synthesis of Functionalized High-Molecular-Weight Polyethylene by Copolymerization of Ethylene with Polar Monomers. Angew. Chem. Int. Ed. 2016, 55, 13281-13285. [CrossRef]

23. Dai, S.; Sui, X.; Chen, C. Highly Robust Palladium(II) $\alpha$-Diimine Catalysts for Slow-Chain-Walking Polymerization of Ethylene and Copolymerization with Methyl Acrylate. Angew. Chem. Int. Ed. 2015, 54, 9948-9953. [CrossRef]

24. Pei, L.; Liu, F.; Liao, H.; Gao, J.; Zhong, L.; Gao, H.; Wu, Q. Synthesis of Polyethylenes with Controlled Branching with $\alpha$-Diimine Nickel Catalysts and Revisiting Formation of Long-Chain Branching. ACS Catal. 2018, 8, 1104-1113. [CrossRef]

25. Soshnikov, I.E.; Bryliakov, K.P.; Antonov, A.A.; Sun, W.-H.; Talsi, E.P. Ethylene polymerization of nickel catalysts with $\alpha$-diimine ligands: Factors controlling the structure of active species and polymer properties. Dalton Trans. 2019, 48, 7974-7984. [CrossRef] [PubMed] 
26. Rose, J.M.; Cherian, A.E.; Coates, G.W. Living Polymerization of $\alpha$-Olefins with an $\alpha$-Diimine Ni(II) Catalyst: Formation of Well-Defined Ethylene-Propylene Copolymers through Controlled Chain-Walking. J. Am. Chem. Soc. 2006, 128, $4186-4187$. [CrossRef] [PubMed]

27. Cherian, A.E.; Rose, J.M.; Lobkovsky, E.B.; Coates, G.W. A C2-Symmetric, Living $\alpha$-Diimine Ni(II) Catalyst: Regioblock Copolymers from Propylene. J. Am. Chem. Soc. 2005, 127, 13770-13771. [CrossRef]

28. De Waele, P.; Jazdzewski, B.A.; Klosin, J.; Murray, R.E.; Theriault, C.N.; Vosejpka, P.C.; Petersen, J.L. Synthesis of Hafnium and Zirconium Imino-Amido Complexes from Bis-imine Ligands. A New Family of Olefin Polymerization Catalysts. Organometallics 2007, 26, 3896-3899. [CrossRef]

29. Froese, R.D.J.; Jazdzewski, B.A.; Klosin, J.; Kuhlman, R.L.; Theriault, C.N.; Welsh, D.M.; Abboud, K.A. Imino-Amido Hf and Zr Complexes: Synthesis, Isomerization, and Olefin Polymerization. Organometallics 2011, 30, 251-262. [CrossRef]

30. Ionkin, A.S.; Marshall, W.J. ortho-5-Methylfuran- and Benzofuran-Substituted $\eta 3$-Allyl( $\alpha$-diimine)nickel(II) Complexes: Syntheses, Structural Characterization, and the First Polymerization Resultst. Organometallics 2004, 23, 3276-3283. [CrossRef]

31. Liu, H.; Zhao, W.; Hao, X.; Redshaw, C.; Huang, W.; Sun, W.-H. 2,6-Dibenzhydryl-N-(2-phenyliminoacenaphthylenylidene)-4methylbenzenamine Nickel Dibromides: Synthesis, Characterization, and Ethylene Polymerization. Organometallics 2011, 30, 2418-2424. [CrossRef]

32. Zhou, Z.; Hao, X.; Redshaw, C.; Chen, L.; Sun, W.-H. Nickel bis\{4,6-dibenzhydryl-2-[(arylimino)methyl]phenoxylate\} complexes: Synthesis, structures, and catalytic behaviour towards ethylene and norbornene. Catal. Sci. Technol. 2012, 2, 1340-1345. [CrossRef]

33. Du, S.; Kong, S.; Shi, Q.; Mao, J.; Guo, C.; Yi, J.; Liang, T.; Sun, W.-H. Enhancing the Activity and Thermal Stability of Nickel Complex Precatalysts Using 1-[2,6-Bis(bis(4-fluorophenyl)methyl)-4-methyl phenylimino]-2-aryliminoacenaphthylene Derivatives. Organometallics 2015, 34, 582-590. [CrossRef]

34. Rhinehart, J.L.; Brown, L.A.; Long, B.K. A Robust Ni(II) $\alpha$-Diimine Catalyst for High Temperature Ethylene Polymerization. J. Am. Chem. Soc. 2013, 135, 16316-16319. [CrossRef] [PubMed]

35. Rhinehart, J.L.; Mitchell, N.E.; Long, B.K. Enhancing $\alpha$-Diimine Catalysts for High-Temperature Ethylene Polymerization. ACS Catal. 2014, 4, 2501-2504. [CrossRef]

36. Zheng, Q.; Zheng, D.; Han, B.; Liu, S.; Li, Z. Chromium complexes supported by the bidentate PN ligands: Synthesis, characterization and application for ethylene polymerization. Dalton Trans. 2018, 47, 13459-13465. [CrossRef]

37. Zhong, L.; Li, G.; Liang, G.; Gao, H.; Wu, Q. Enhancing Thermal Stability and Living Fashion in $\alpha$-Diimine-Nickel-Catalyzed (Co)polymerization of Ethylene and Polar Monomer by Increasing the Steric Bulk of Ligand Backbone. Macromolecules 2017, 50, 2675-2682. [CrossRef]

38. Liao, Y.; Zhang, Y.; Cui, L.; Mu, H.; Jian, Z. Pentiptycenyl Substituents in Insertion Polymerization with $\alpha$-Diimine Nickel and Palladium Species. Organometallics 2019, 38, 2075-2083. [CrossRef]

39. Zou, W.; Chen, C. Influence of Backbone Substituents on the Ethylene (Co)polymerization Properties of $\alpha$-diimine Pd(II) and $\mathrm{Ni}(\mathrm{II})$ Catalysts. Organometallics 2016, 35, 1794-1801. [CrossRef]

40. Guo, L.; Gao, H.; Guan, Q.; Hu, H.; Deng, J.; Liu, J.; Liu, F.; Wu, Q. Substituent Effects of the Backbone in $\alpha$-Diimine Palladium Catalysts on Homo- and Copolymerization of Ethylene with Methyl Acrylate. Organometallics 2012, 31, 6054-6062. [CrossRef]

41. Liu, J.; Chen, D.; Wu, H.; Xiao, Z.; Gao, H.; Zhu, F.; Wu, Q. Polymerization of $\alpha$-Olefins Using a Camphyl $\alpha$-Diimine Nickel Catalyst at Elevated Temperature. Macromolecules 2014, 47, 3325-3331. [CrossRef]

42. Liu, F.-S.; Hu, H.-B.; Xu, Y.; Guo, L.-H.; Zai, S.-B.; Song, K.-M.; Gao, H.-Y.; Zhang, L.; Zhu, F.-M.; Wu, Q. Thermostable $\alpha$-Diimine Nickel(II) Catalyst for Ethylene Polymerization: Effects of the Substituted Backbone Structure on Catalytic Properties and Branching Structure of Polyethylene. Macromolecules 2009, 42, 7789-7796. [CrossRef]

43. Han, B.; Liu, Y.; Feng, C.; Liu, S.; Li, Z. Development of Group 4 Metal Complexes Bearing Fused-Ring Amido-Trihydroquinoline Ligands with Improved High-Temperature Catalytic Performance toward Olefin (Co)polymerization. Organometallics 2021, 40, 242-252. [CrossRef]

44. Klosin, J.; Fontaine, P.P.; Figueroa, R. Development of Group IV Molecular Catalysts for High Temperature Ethylene- $\alpha$-Olefin Copolymerization Reactions. Acc. Chem. Res. 2015, 48, 2004-2016. [CrossRef] [PubMed]

45. Fontaine, P.P.; Ueligger, S.; Klosin, J.; Hazari, A.; Daller, J.; Hou, J. Development of Improved Amidoquinoline Polyolefin Catalysts with Ultrahigh Molecular Weight Capacity. Organometallics 2015, 34, 1354-1363. [CrossRef]

46. Klosin, J.; Fontaine, P.P.; Figueroa, R.; McCann, S.D.; Mort, D. Preparation of New Olefin Polymerization Precatalysts by Facile Derivatization of Imino-Enamido ZrMe3 and HfMe3 Complexes. Organometallics 2013, 32, 6488-6499. [CrossRef]

47. Fontaine, P.P.; Figueroa, R.; McCann, S.D.; Mort, D.; Klosin, J. Synthesis and Scale-up of Imino-Enamido Hafnium and Zirconium Olefin Polymerization Catalysts. Organometallics 2013, 32, 2963-2972. [CrossRef]

48. Fontaine, P.P.; Klosin, J.; McDougal, N.T. Hafnium Amidoquinoline Complexes: Highly Active Olefin Polymerization Catalysts with Ultrahigh Molecular Weight Capacity. Organometallics 2012, 31, 6244-6251. [CrossRef]

49. Figueroa, R.; Froese, R.D.; He, Y.; Klosin, J.; Theriault, C.N.; Abboud, K.A. Synthesis of Imino-Enamido Hafnium and Zirconium Complexes: A New Family of Olefin Polymerization Catalysts with Ultrahigh-Molecular-Weight Capabilities. Organometallics 2011, 30, 1695-1709. [CrossRef]

50. Antonov, A.A.; Bryliakov, K.P. Post-metallocene catalysts for the synthesis of ultrahigh molecular weight polyethylene: Recent advances. Eur. Polym. J. 2021, 142, 110162. [CrossRef] 
51. Patel, K.; Chikkali, S.H.; Sivaram, S. Ultrahigh molecular weight polyethylene: Catalysis, structure, properties, processing and applications. Prog. Polym. Sci. 2020, 109, 101290. [CrossRef]

52. Zhang, C.; Pan, H.; Klosin, J.; Tu, S.; Jaganathan, A.; Fontaine, P.P. Synthetic Optimization and Scale-Up of Imino-Amido Hafnium and Zirconium Olefin Polymerization Catalysts. Org. Process. Res. Dev. 2015, 19, 1383-1391. [CrossRef]

53. Liu, S.; Xing, Y.; Zheng, Q.; Jia, Y.; Li, Z. Synthesis of Anthracene-Bridged Dinuclear Phenoxyiminato Organotitanium Catalysts with Enhanced Activity, Thermal Stability, and Comonomer Incorporation Ability toward Ethylene (Co)polymerization. Organometallics 2020, 39, 3268-3274. [CrossRef]

54. Dieck, H.T.; Kollvitz, W.; Rohde, W.; Stamp, L. Ruthenium complexes with diazadienes, Part V(1).Cis-Dicarbonyl-1,4-diaza-1,3diene-trans-diiodoruthenium Complexes; synthesis, properties and the crystal structure of [(DAD)Ru(CO)2I2] DAD (DAD=ptolyl-N=CMe-CMe=N-p-tolyl). Transit. Met. Chem. 1986, 11, 361-366. [CrossRef]

55. Galindo, A.; Ienco, A.; Mealli, C. Nature of the metal-carbon contacts in ene-diamido d0 metal complexes. New J. Chem. 2000, 24, 73-75. [CrossRef] 